\title{
The Abundance and Biting Patterns of Culex quinquefasciatus Say (Culicidae) in the Coastal Region of Nigeria
}

\author{
Emmanuel C. Uttah, ${ }^{1,2}$ Gloria N. Wokem, ${ }^{3}$ and Christiana Okonofua ${ }^{4}$ \\ ${ }^{1}$ Department of Animal and Environmental Biology, University of Port Harcourt, Port Harcourt, Nigeria \\ ${ }^{2}$ Department of Biological Science, Cross River University of Technology, Calabar, Nigeria \\ ${ }^{3}$ Department of Medical Laboratory Sciences, Rivers State University of Science and Technology, Port Harcourt, Nigeria \\ ${ }^{4}$ Department of Biological Sciences, Microbiology Unit, Crawford University, Igbesa, Ogun State, Nigeria
}

Correspondence should be addressed to Emmanuel C. Uttah; drecuttah@yahoo.com

Received 19 January 2013; Accepted 19 February 2013

Academic Editors: K. Lunau, D. Park, V. Tilgar, and S. Van Nouhuys

Copyright (C) 2013 Emmanuel C. Uttah et al. This is an open access article distributed under the Creative Commons Attribution License, which permits unrestricted use, distribution, and reproduction in any medium, provided the original work is properly cited.

\begin{abstract}
This study was aimed at determining the abundance and biting patterns of Culex quinquefasciatus in the coastal region of Nigeria. Collections were done by human landing catch and by CDC miniature light traps from September 2005 to August 2006. A total of 3798 C. quinquefasciatus females were collected. The highest number of females was caught in the month of August and it represented nearly a quarter $(24.0 \%)$ of the total females collected. In all, $38.8 \%$ of females dissected were parous. The abundance of C. quinquefasciatus followed the pattern of rainfall with the population starting to expand at the onset of the rains. The highest increase was found after the temperature had peaked. The mean of biting was 3.2 times more in the rainy season than in the dry season, whereas the transmission potential was higher in the dry season. C. quinquefasciatus is presently regarded as a biting nuisance having no significant epidemiological importance yet. Efforts at its control should be intensified before it is too late.
\end{abstract}

\section{Introduction}

C. quinquefasciatus Say is a cosmopolitan mosquito with worldwide distribution, especially in the tropical and subtropical areas and is associated with human dwellings. The adult females lay eggs preferentially in relatively large, permanent aquatic habitats with high concentrations of decomposing organic matter, such as sewage effluents and septic tanks. However, immature stages of this species can be found in artificial containers often filled with polluted or organicrich water but rarely coexist in the same container with the dengue vector Aedes aegypti [1].

C. quinquefasciatus, the southern house mosquito, has been relatively well studied in recent years probably because of its role in the transmission of important human diseases such as urban lymphatic filariasis, Saint Louis encephalitis virus (SLEV), and Western equine encephalitis virus [2, 3]. In the West Africa subregion, Culex mosquitoes are not filariasis vectors yet. They are potential vectors as there is minimal evidence that Culex mosquitoes contribute to the transmission of the disease [4].

The process of rapid urbanization and unplanned growth of cities has resulted in the production of mosquito habitats enhancing the breeding of a variety of disease vectors and consequently disease transmission [5]. Using gutters, drainage channels and other sources of organically rich, stagnant water for oviposition and larval development [6, 7], C. pipiens mosquitoes are usually abundant in urban environments. They feed on men, birds, and mammals $[8,9]$. Their feeding on birds makes them the ideal vector for avian pathogens like WNV and SLEV [10-12]. Their feeding on humans and other mammals results in their serving as an important bridge vector [13-15]. The preferred biting region in humans is the foot region [16].

In addition to its public health importance, C. quinquefasciatus causes tremendous nocturnal discomfort and allergic responses due to its nuisance biting [1]. The nuisance biting usually affects a greater proportion of the population than the 
proportion habouring diseases transmitted by the mosquito species. Sometimes the nuisance level could be extremely high and intolerable. This situation is compounded by the fact that the susceptibility of $C$. quinquefasciatus to pyrethroids such as permethrin and deltamethrin is relatively lower than those of the anophelines such as Anopheles gambiae s.l. and An. funestus s.l. [17].

Discovering an efficient cost-effective control measures against C. quinquefasciatus and indeed other vectors and nuisance biters has remained the priority of scientists worldwide for a long time. Since the ecological plasticity of $C$. quinquefasciatus may be useful in the determination of a costeffective control policy [1], the need for a comprehensive study to ascertain the biting characteristics of the mosquito species cannot be overemphasized. Furthermore, a study on the parity of the mosquitoes will provide a baseline data needed to measure effectiveness of control measures. To the best of our knowledge, no such work has yet been reported in Nigeria. This study is therefore aimed at determining the abundance and biting patterns of $C$. quinquefasciatus in the coastal region of Nigeria.

\section{Materials and Methods}

2.1. Collection and Examination of C. quinquefasciatus. The adult mosquitoes were sampled during the night by CDC miniature light traps (LTs) and by human landing catches (HLCs). A four-man team of collectors did all the mosquito collection. Every week, during 12 months from September 2005 to August 2006, a total of 2 night-time HLC and 2 nights of LT collections (6 LTs each night) were carried out.

The study was conducted in Umuowa Ibu in Okigwe Local Government Area, Imo State, Nigeria. It is a homogenous community of the indigenous Ibo people, the predominant tribe in southeastern Nigeria. Their houses are arranged in familial settlement pattern as the houses are arranged in family clusters. The area is hilly with characteristic undulating plains. There are a total of seven streams and three rivers in the area, and farming is the main occupation. Other predominant occupations include fishing, trading, and artisan work.

Human landing catches at night were performed in a centrally located house in Umuowa Ibu. The catching team of four alternated pairwise between collecting and resting. Each pair of collectors were collecting for one hour and resting the following hour as the other pair was collecting. The collectors exposed their feet and legs up to the knee, and mosquitoes were collected using aspirators. Collections started outdoors at 1800 hours, continuing until 2200 hours, when the villagers normally went to bed. Indoor collections thus started at 2200 hours and continued till 0600 hours. The pairings of collectors and working hours were systematically shifted on each catching day to eliminate any possible bias that could arise from each individual's attractability and catching prowess. Hourly collections of mosquitoes were kept separately in labeled cups, which were covered with fine nylon nets held with rubber bands. After each hourly collection, the cups with mosquitoes were provided with a pad of wet cotton wool on the top and kept cool in an insulated box with cooling elements until the mosquitoes could be identified and dissected.

The light trap catches were performed simultaneously with the human landing night catches. Each trapping night $C$. quinquefasciatus were collected with light traps in six houses. These houses were chosen to represent all parts of the study areas as well as the three different house types observed. The light traps were used in rooms were only one occupant slept. The occupant was taught how to turn-on and turn-off the trap and also given an unimpregnated bed-net for use around the bed while sleeping. The traps were turned on at 1800 hours and turned off at 0600 hours. They were emptied and the collected mosquitoes were kept in cool boxes until identified and possibly dissected.

2.2. Dissection of C. quinquefasciatus Females in the Laboratory. At the end of each catching week, the collected mosquitoes were brought to the base laboratory to be identified and dissected. C. quinquefasciatus were sexed and identified based on external morphology after Gillies and Coetzee [18], Gillies and de Meillon [19], and Edwards [20].

All alive and identified female C. quinquefasciatus caught during the night by the human landing catch method were dissected, whereas only randomly selected samples of those caught in the light traps were dissected. The identified $C$. quinquefasciatus were knocked down with ether and kept in petri-dishes with moist cotton wool to prevent desiccation. After removal of legs and wings, C. quinquefasciatus females were placed on a slide in a drop of saline, and the ovaries were extracted and quickly transferred to a drop of distilled water on the slide where they are left to dry before being examined under high magnification for tracheal skeins and classified as parous or nulliparous [21]. All females C. quinquefasciatus were dissected fully whether parous or nulliparous.

2.3. Data Analysis. For the entomological and clinical surveys, the SPSS for Windows package was used in the entering of data, and $P$ values $<0.05$ were also considered statistically significant in the statistical tests. The Mantel Haenszel test, stratifying for season, was used in comparing pairs of percentage parous females between the dry (from November to March) and rainy (from April to October) seasons. Parous rate was calculated as follows:

$$
\text { parous rate }=\frac{\text { no. of parous females }}{\text { no. females dissected }} \times 100
$$

Circadian pattern of biting and parity patterns were analyzed to verify the hours of most intense biting and most intense parous biting, respectively; chi-square test was used for the analysis.

\section{Results}

3.1. Abundance and Seasonality. The six light traps caught a total of 5699 females out of which 929 (36.7\%) were parous. The monthly relative abundance of $C$. quinquefasciatus by human landing catch is presented in the Table 1. A total of 3798 C. quinquefasciatus females were collected, out of 
TABLE 1: The monthly entomological indices for C. quinquefasciatus in the coastal region of Nigeria, based on human landing catch.

\begin{tabular}{|c|c|c|c|c|c|}
\hline Month & Collected (\%) & Dissected (proportion \%) & Parous (proportion\%) & Rainfall (mm) & Temperature $\left({ }^{\circ} \mathrm{C}\right)$ \\
\hline September 2005 & $69(1.8)$ & $45(65.2)$ & $19(42.2)$ & 370 & 26.8 \\
\hline October 2005 & $58(1.5)$ & $43(74.1)$ & $22(51.2)$ & 440 & 25.8 \\
\hline November 2005 & $37(1.0)$ & $25(67.6)$ & $17(68.0)$ & 80 & 25.2 \\
\hline December 2005 & $89(2.3)$ & $79(88.8)$ & $42(53.2)$ & 18 & 26.8 \\
\hline January 2006 & $178(4.7)$ & $138(77.5)$ & $80(58.0)$ & 12 & 27.7 \\
\hline February 2006 & $310(8.2)$ & $235(75.8)$ & $99(42.1)$ & 40 & 27.8 \\
\hline March 2006 & $281(7.4)$ & $206(73.3)$ & $93(45.1)$ & 190 & 27.4 \\
\hline April 2006 & $274(7.2)$ & $240(87.6)$ & $91(37.9)$ & 330 & 27.3 \\
\hline May 2006 & $444(11.7)$ & $328(73.9)$ & $95(29.0)$ & 240 & 27.4 \\
\hline June 2006 & $617(16.2)$ & $535(86.7)$ & $220(41.1)$ & 260 & 27.0 \\
\hline July 2006 & $540(14.2)$ & $466(86.3)$ & $159(34.1)$ & 240 & 24.7 \\
\hline August 2006 & $901(24.0)$ & $774(85.9)$ & $272(35.1)$ & 440 & 25.0 \\
\hline Total & $3798(100)$ & $3114(82.0)$ & $1209(38.8)$ & 2660 & \\
\hline
\end{tabular}

which $82.0 \%$ survived till they were dissected. The highest number of females was caught in the month of August, and it represented nearly a quarter $(24.0 \%)$ of the total annual collection of 3798 . The least number of females was caught in the month of November and represented $1.0 \%$ of the total annual collection. In all, $38.8 \%$ of females dissected were parous. The highest parous rate $(68.0 \%)$ was observed in the month of November, while the least $(29.0 \%)$ was in the month of May.

In all, $82.0 \%$ of all captured females remained alive and were dissected, out of which $38.8 \%$ were parous. The parous rate was significantly higher in the dry season (48.5\%; from November to March) than in the rainy season (36.1\%; from April to October) ( $\chi^{2}$-test; $P<0.001$ for both tests). The highest percentage of parous female $(68.0 \%)$ was obtained in the dry month of November, while the least percentage (29.0\%) was obtained in the rainy month of May.

The abundance of $C$. quinquefasciatus followed the pattern of rainfall, and the population started to expand at the onset of the rains. The highest increase was found after the temperature had peaked.

3.2. Circadian Biting Pattern. The circadian biting activities of C. quinquefasciatus is presented in Table 2. C. quinquefasciatus was as frequent outdoors as it was indoors. The outdoor collections constituted $47.9 \%$ of total collections. The peak of circadian biting was between 18.00 and 20.00 hours outdoors, but biting declined steadily to the lowest level between 03.00 and 04.00 hours before rising again.

3.3. Parous Rates. The circadian variation in parity of $C$. quinquefasciatus was observed (see Table 3 ). The highest parity rate was $51.7 \%$ collected from 22.00 to 23.00 hours. Relatively higher parity rates were observed in the early part of the night, during the outdoor catches. The lowest percentage of parous females $(28.4 \%)$ was caught between 05.00 and 06.00 hours in the morning. The percentage of parous females collected between the peak from 22.00 to $02.00(46.7 \%)$ was significantly higher than the percentage
TABle 2: Circadian biting activity of human landing night $C$. quinquefasciatus in the coastal region of Nigeria.

\begin{tabular}{lc}
\hline Time & Number of females (\%) \\
\hline $18.00-19.00$ & $485(12.8)$ \\
$19.00-20.00$ & $500(13.1)$ \\
$20.00-21.00$ & $439(11.6)$ \\
$21.00-22.00$ & $395(10.4)$ \\
\hline Total out-door & $1819(47.9)$ \\
\hline $22.00-23.00$ & $328(8.6)$ \\
$23.00-00.00$ & $350(9.2)$ \\
$00.00-01.00$ & $315(8.3)$ \\
$01.00-02.00$ & $279(7.3)$ \\
$02.00-03.00$ & $178(4.7)$ \\
$03.00-04.00$ & $112(2.9)$ \\
$04.00-05.00$ & $166(4.4)$ \\
$05.00-06.00$ & $251(6.6)$ \\
\hline Total indoor & $1979(52.1)$ \\
\hline Overall total & $3798(100.0)$ \\
\hline
\end{tabular}

of parous females collected the rest of the night $(35.0 \%)\left(\chi^{2}\right.$ test; $P<0.001)$. Parity was inversely proportional to relative abundance of $C$. quinquefasciatus.

For C. quinquefasciatus, more females also survived until dissected in the rainy season than in the dry season, and the difference was statistically significant $\left(\chi_{\mathrm{M}-\mathrm{H}}^{2}=25.56 ; P<\right.$ 0.001 ). The mean of biting was 3.2 times more in the rainy season than in the dry season, whereas the transmission potential was higher in the dry season (see Table 4).

\section{Discussion}

4.1. Abundance and Seasonality. Previous studies in the neighbouring Igwun River Basin indicated that potential culicine mosquito vectors of $W$. bancrofti were abundant in the area [22]. C. quinquefasciatus was the second most abundant, making up to $38.3 \%$ of the total number of 
TABLE 3: Circadian variation in parity of human landing mosquitoes in the coastal region of Nigeria.

\begin{tabular}{lcc}
\hline Time & Number dissected & Number parous (\%) \\
\hline $18.00-19.00$ & 394 & $134(34.0)$ \\
$19.00-20.00$ & 401 & $115(37.4)$ \\
$20.00-21.00$ & 360 & $130(36.1)$ \\
$21.00-22.00$ & 321 & $125(38.9)$ \\
$22.00-23.00$ & 261 & $135(51.7)$ \\
$23.00-00.00$ & 270 & $127(47.0)$ \\
$00.00-01.00$ & 253 & $119(47.0)$ \\
$01.00-02.00$ & 228 & $92(40.4)$ \\
$02.00-03.00$ & 157 & $55(35.0)$ \\
$03.00-04.00$ & 104 & $34(32.7)$ \\
$04.00-05.00$ & 147 & $46(31.3)$ \\
$05.00-06.00$ & 218 & $62(28.4)$ \\
\hline Total & 3114 & $1209(38.8)$ \\
\hline
\end{tabular}

TABle 4: Dry season and rainy season entomological indices for C. quinquefasciatus in relation to seasons in the coastal region of Nigeria, based on human landing catch.

\begin{tabular}{lcc}
\hline Description & Dry season & Rainy season \\
\hline Total number of days & 152 & 214 \\
Number of catch days & 22 & 30 \\
Number of females collected & $895(23.6 \%)$ & $2903(76.4 \%)$ \\
Number of females dissected (\%) & $683(76.3 \%)$ & $2431(83.7 \%)$ \\
Number parous (\%) & $331(48.5)$ & $878(36.1)$ \\
Seasonal biting rate & 3290 & 10557 \\
\hline
\end{tabular}

mosquitoes caught in the Lower Imo River Basin study area. There were marked seasonal variations in the mosquito abundance. All the mosquito species were more abundant during the rainy season than during the dry season. This agrees with the patterns observed by Lindsay et al. [23] and by Gajanana et al. [24]. This is understandable as the rains make more breeding sites available. The seasonality of abundance of mosquito vectors has been reported from many other endemic areas including Pondicherry in India [25]. The service [26] observed that peaks of biting by C. pipiens quinquefasciatus took place from March to May (late dry to early wet season) and in September (late wet season) in northern Nigeria.

Peaks in female mosquito densities were in the rainy season and at the beginning of dry season in urban areas in Upper Volta [27], in rural areas [28], and in the beginning of the rainy season in Kaduna, northern Nigeria [26]. The mean densities in West Africa in the rainy season are often ten times as high as dry season densities [27].

Factors other than climate and availability of breeding sites may affect the population density [29]. One of such factors is the ability of vectors to exploit human activities to their advantage, for example, for breeding and perpetuation of self. The breeding habit of $C$. quinquefasciatus is very interesting as it tends to exploit the food processing habits of the people in the Imo River Basin study areas, whose staple food is fermented cassava, Manihot utillissema. The cassava is fermented in water for days to get rid of poisonous cyanide. Fermentation by soaking is an effective processing method that reduces all cyanogenic substances to negligible levels [30-32], thus making cassava a safe commodity for consumption [33]. This practice is more pronounced in the high altitude area than in the coastal area [34]. C. quinquefasciatus in the Imo River Basin area breed in pots of fermenting cassava, which is another example of successful exploitation of peoples' habits for self-perpetuation by the vectors. The breeding of C. quinquefasciatus in pots of fermenting cassava has also been reported in the Nsukka area of eastern Nigeria [35]. Similarly, Udonsi [22] reported on a great abundance of Culex sp. in the Igwun River Basin where this food processing method is also common. This food processing habit is an allyear-round practice and may therefore ensure an all-yearround breeding of $C$. quinquefasciatus. This is in line with the contention that human activity is altering the pattern of disease transmission in the tropics $[36,37]$.

C. quinquefasciatus is normally known to breed in open drains, open or cracked septic tanks, flooded pit latrines and drains, especially when polluted with organic matter $[1,38]$. Other breeding sites for C. quinquefasciatus in the area include natural containers of decaying Mbele fruits and broken suckaways. It also breeds in septic tanks in neighbouring Okigwe town [29].

The temperature tended to have an inverse relationship with the relative mosquito abundance, whereas rainfall had a positive relationship with the relative abundance of $C$. quinquefasciatus in both parts of the Imo River Basin. In Brazil, the monthly density did not correlate with temperature and rainfall [1].

The annual biting rate (ABR) (an estimate of the number of a particular vector coming to bite one person who is exposed to biting during all biting hours of the vector every day for one year) for C. quinquefasciatus was 13,847 bites/person/year (HLC) and 10,128 bites/person/year (LT) in the Lower Imo River Basin study area. Annual biting rates vary from place to place and sometimes from year to year. The $\mathrm{ABR}$ for C. quinquefasciatus in this study disagrees with the old popular belief that the biting rate of $C$. quinquefasciatus is a good indicator of degree of urbanization of an area. With its ability to exploit human behavior for its own perpetuation as exemplified in this study, C. quinquefasciatus is increasingly colonizing nonurban areas.

4.2. Circadian Biting Pattern. The circadian biting of $C$. quinquefasciatus showed a peak between 18.00 and 20.00 hours outdoors in the Lower Imo River Basin study area. This is contrary to earlier studies which showed peak biting after midnight in West Africa [27] and East Africa where it is an established vector [39]. Our study was adapted after the routine times of the local people in that the mosquito sampling was done outdoors during the time the people usually stayed outdoors (up till 22.00 hours) and inside (22.0006.00) when they were normally indoors. An individual in the Lower Imo River Basin study area received 52.1\% of $C$. quinquefasciatus bites while outdoor and $47.9 \%$ while indoor. 
It is known that abundance, attractiveness, and availability of the human host is influencing vector biting behavior [40]. For C. pipiens fatigans, the human density has been shown to be of primary importance.

The parous rate was higher in the dry season thereby increasing the transmission potential during that period. The parity rate in this study was lower than reported in Tanzania [41]. The rainy season is longer than the dry season in the study area. The percentage of females of C. quinquefasciatus that survived from the period of collection until dissected during the rainy season was significantly higher than during the dry season. This may be explained due to marked differences in humidity levels between the seasons. There was a preponderance of older mosquitoes during the dry season compared to the rainy season, as shown by the higher parity rates in the former than in the latter. This was contrary to the findings in Brazil where there were a higher proportion of nulliparous females during the dryer months, while gravid females were more frequent in rainy months [1]. This of course could not be due to a higher mortality during the rainy season because the higher humidity level during this season provides favorable conditions for survival as has been shown by higher survival of females kept for dissection in the rainy season than during the dry season. The explanation is a higher production of nulliparous mosquitoes during the rainy season due to the availability of more breeding sites.

The C. quinquefasciatus is a potential vector of filariasis that may have serious consequences for filariasis epidemiology in rural parts of West Africa. In the passing of time, it may become epidemiologically important not only in the transmission of urban filariasis but also in the transmission of rural filariasis in Nigeria and in West Africa as a whole. In an experiment in the laboratory in Nigeria, $76.6 \%$ of this mosquito species harboured infective $\mathrm{L}_{3}$ larvae indicating compatibility between the local strain of the filarial parasite and this species of mosquito in this area [42]. The possible involvement of Culex species in the transmission of lymphatic filariasis in northern Nigeria was suggested much earlier, while $W$. bancrofti larvae have been found in C. antennatus [43]. Culexes, together with Anopheles and Aedes species, have been incriminated as vectors of bancroftian filariasis in different ecological zones of the world [44-47]. C. quinquefasciatus has steadily assumed increasing importance as a vector in urban areas in the Caribbean, Latin America, China, Egypt, South Asia [42], and in also East Africa [48]. The movement of infected people from rural West Africa in the large West African urban centers, where C. quinquefasciatus is now well established, could lead to $W$. bancrofti becoming increasingly well adapted to C. quinquefasciatus $[43,49,50]$. This could open a new vista of epidemiological challenges in the transmission of filariasis in the West African region.

\section{Conclusion}

C. quinquefasciatus is presently regarded as a biting nuisance having no significant epidemiological importance yet. Research indications are that it could become important in filariasis transmission in West Africa as it is currently in East
Africa. Efforts at its control should be intensified before it is too late as a stitch in time saves nine.

\section{Acknowledgments}

The contributions of the human bait team made up of Edwin Uttah, Jacob Ndukwu, Stephen Uttah, Verny, and Francis Uttah and the field support team comprised of Bassey Cobham and Christopher Uzoma are highly appreciated. The assistance received from the laboratory personnel Mr. Akpan and Comfort Nwankwoala are hereby acknowledged.

\section{References}

[1] M. R. David, G. S. Ribeiro, and R. M. de Freitas, "Bionomics of Culex quinquefasciatus within urban areas of Rio de Janeiro, Southeastern Brazil," Revista de Saúde Pública, vol. 46, no. 5, pp. 858-865, 2012.

[2] W. K. Reisen, H. D. Lothrop, and B. Lothrop, "Factors influencing the outcome of mark-release-recapture studies with Culex tarsalis (Diptera: Culicidae)," Journal of Medical Entomology, vol. 40, no. 6, pp. 820-829, 2003.

[3] C. E. Jones, L. P. Lounibos, P. P. Marra, and A. M. Kilpatrick, "Rainfall influences survival of Culex pipiens (Diptera: Culicidae) in a residential neighborhood in the mid-atlantic United States," Journal of Medical Entomology, vol. 49, no. 3, pp. 467473, 2012.

[4] D. K. de Souza, B. Koudou, L. A. Kelly-Hope, M. D. Wilson, M. J. Bockarie, and D. A. Boakye, "Diversity and transmission competence in lymphatic filariasis vectors in West Africa, and the implications for accelerated elimination of Anophelestransmitted filariasis," Parasites \& Vectors, vol. 5, article 259, 2012.

[5] A. E. Jamal, A. D. Nugud, M. A. Abdalmagid, A. I. Bashir, M. Brair, and I. H. Elnaeim, "Susceptibility of Culex quinquefasciatus Say (Diptera: Culicidae) in Khartoum locality (Sudan) to Malathion, Temephos, Lambdacyhalothrin and Permethrin insecticides," Sudanese Journal of Public Health, vol. 6, no. 2, pp. 56-62, 2011.

[6] A. Spielman and M. D’Antonio, Mosquito: A Natural History of Our Most Persistent and deadly Foe, Hyperion, New York, NY, USA, 2001.

[7] T. G. Andreadis, M. C. Thomas, and J. J. Shepard, Identification Guide to the Mosquitoes of Connecticut, The Connecticut Agricultural Experiment Station, New Haven, Conn, USA, 2005.

[8] M. Zinser, F. Ramberg, and E. Willott, "Culex quinquefasciatus (Diptera: Culicidae) as a potential West Nile virus vector in Tucson, Arizona: blood meal analysis indicates feeding on both humans and birds," Journal of Insect Science, vol. 4, article 20, 2004.

[9] G. Molaei, T. G. Andreadis, P. M. Armstrong et al., "Host feeding pattern of Culex quinquefasciatus (Diptera: Culicidae) and its role in transmission of West Nile virus in Harris County, Texas," The American Journal of Tropical Medicine and Hygiene, vol. 77, no. 1, pp. 73-81, 2007.

[10] A. M. Kilpatrick, P. Daszak, M. J. Jones, P. P. Marra, and L. D. Kramer, "Host heterogeneity dominates West Nile virus transmission," Proceedings of the Royal Society B, vol. 273, no. 1599, pp. 2327-2333, 2006.

[11] G. Molaei, T. G. Andreadis, P. M. Armstrong, J. F. Anderson, and C. R. Vossbrinck, "Host feeding patterns of Culex mosquitoes 
and west nile virus transmission, northeastern United States," Emerging Infectious Diseases, vol. 12, no. 3, pp. 468-474, 2006.

[12] G. L. Hamer, U. D. Kitron, T. L. Goldberg et al., "Host selection by Culex pipiens mosquitoes and west nile virus amplification," The American Journal of Tropical Medicine and Hygiene, vol. 80, no. 2, pp. 268-278, 2009.

[13] A. M. Kilpatrick, L. D. Kramer, S. R. Campbell, E. O. Alleyne, A. P. Dobson, and P. Daszak, "West Nile virus risk assessment and the bridge vector paradigm," Emerging Infectious Diseases, vol. 11, no. 3, pp. 425-429, 2005.

[14] A. M. Kilpatrick, L. D. Kramer, M. J. Jones, P. P. Marra, and P. Daszak, "West Nile virus epidemics in North America are driven by shifts in mosquito feeding behavior," PLoS Biology, vol. 4, no. 4, pp. 606-610, 2006.

[15] G. L. Hamer, U. D. Kitron, J. D. Brawn et al., "Culex pipiens (Diptera: Culicidae): a bridge vector of West Nile virus to humans," Journal of Medical Entomology, vol. 45, no. 1, pp. 125128, 2008.

[16] A. O. Oduola and O. O. Awe, "Behavioural biting preference of Culex quinquefasciatus in human host in Lagos metropolis Nigeria," Journal of Vector Borne Diseases, vol. 43, no. 1, pp. 1620, 2006.

[17] M. A. Kulkarni, R. Malima, F. W. Mosha et al., "Efficacy of pyrethroid-treated nets against malaria vectors and nuisance-biting mosquitoes in Tanzania in areas with long-term insecticide-treated net use," Tropical Medicine \& International Health, vol. 12, no. 9, pp. 1061-1073, 2007.

[18] M. T. Gillies and M. Coetzee, A Supplement to the Anophelinae of Africa South of the Sahara (Afro-Tropical Region), Publication of South African Institute of Medical Research, No. 55, 1987.

[19] M. T. Gillies and B. de Meillon, The Anophelinae of Africa South of the Sahara (Ethiopian Zoogeographical Region), Publications of the South African Institute for Medical Research, No. 54, 1968.

[20] F. W. Edwards, Mosquitoes of the Ethiopian Region III. Culicidae Adult and Pupae Anopheles Mosquitoes, vol. 23, Publication of the Institute Medical Research, 1941.

[21] World Health Organization, Manual on Practical Entomology in Malaria: Vector Bionomics and Organization, Offset Publication, Geneva, Switzerland, 1975.

[22] J. K. Udonsi, "Filariasis in the Igwun River Basin, Nigeria: an epidemiological and clinical study with a note on the vectors," Annals of Tropical Medicine and Parasitology, vol. 82, no. 1, pp. 75-82, 1988.

[23] S. W. Lindsay, F. C. Shenton, R. W. Snow, and B. M. Greenwood, "Responses of Anopheles gambiae complex mosquitoes to the use of untreated bednets in The Gambia," Medical and Veterinary Entomology, vol. 3, no. 3, pp. 253-262, 1989.

[24] A. Gajanana, R. Rajendran, P. P. Samuel et al., "Japanese encephalitis in South Arcot district, Tamil Nadu, India: a threeyear longitudinal study of vector abundance and infection frequency," Journal of Medical Entomology, vol. 34, no. 6, pp. 651-659, 1997.

[25] K. D. Ramaiah and P. K. Das, "Seasonality of adult Culex quinquefasciatus and transmission of bancroftian filariasis in pondicherry, South India," Acta Tropica, vol. 50, no. 4, pp. 275283, 1992.

[26] M. W. Service, "Ecology of mosquitoes of Northern Guinea Savannah of Nigeria," Bulletin of Entomological Research, vol. 54, pp. 601-632, 1963.
[27] R. Subra, "Biology and control of Culex pipiens quinquefasciatus, Say, 1823 (Diptera: Culicidae) with special reference to Africa," Insect Science and Its Application, vol. 4, pp. 319-338, 1981.

[28] J. Hamon, "Etude de l'age physiologique des femelles d'anophèles dans les zones traitees au DDT, et non traitdes, de la region de Bobo-Dioulasso, Haute Volta," Bulletin of the World Health Organization, vol. 28, article 83, 1963.

[29] B. E. B. Nwoke, F. O. Nduka, O. M. Okereke, and O. C. Ehighibe, "Sustainable urban development and human health: septic tank as a major breeding habitat of mosquito vectors of human diseases in south-eastern Nigeria," Applied Parasitology, vol. 34, no. 1, pp. 1-10, 1993.

[30] P. Bourdoux, P. Seghers, M. Mafuta et al., "Cassava products: HCN content and detoxification processes," in Nutritional Factors Involved in Goitrogenic Action of Cassava, F. Delange, F. Iteke, and Ermams, Eds., vol. 184, pp. 51-58, International Development Research Centre, Ottawa, Canada, IDRC Monograph, 1982.

[31] World Health Organization, "Konzo, a distinct type of upper motor neuron disease," Weekly Epidemiological Record, vol. 71, no. 30, pp. 225-232, 1996.

[32] J. P. Banea-Mayambu, T. Tylleskär, N. Gitebo, N. Matadi, M. Gebre-Medhin, and H. Rosling, "Geographical and seasonal association between linamarin and cyanide exposure from cassava and the upper motor neurone disease konzo in former Zaire," Tropical Medicine and International Health, vol. 2, no. 12, pp. 1143-1151, 1997.

[33] T. Tylleskar, M. Banea, N. Bikangi, R. D. Cooke, N. H. Poulter, and H. Rosling, "Cassava cyanogens and konzo, an upper motoneuron disease found in Africa," The Lancet, vol. 339, no. 8787, pp. 208-211, 1992.

[34] E. C. Uttah, P. E. Simonsen, E. M. Pedersen, and J. K. Udonsi, "Public health dimensions of Cassava processing in Eastern Nigeria," International Journal of Social Sciences, vol. 4, no. 1, pp. 22-33, 2005.

[35] M. O. E. Iwuala, "Cassava fermentation pools as major breeding foci for culicine mosquitoes in Nsukka Nigeria," The Nigerian Medical Journal, vol. 9, no. 3, pp. 327-335, 1979.

[36] L. D. Edungbola, "Water utilization and its health implications in Ilorin, Kwara State, Nigeria," Acta Tropica, vol. 37, no. 1, pp. 73-81, 1980.

[37] B. A. Southgate, "Recent advances in the epidemiology and control of filarial infections including entomological aspects of transmission," Transactions of the Royal Society of Tropical Medicine and Hygiene, vol. 78, pp. 19-28, 1984.

[38] B. E. B. Nwoke and J. Ebo, "Human activities in Southeastern Nigerian and their potential danger to the breeding of mosquito vectors of human diseases," Annals of Medical Sciences, 1993.

[39] E. M. Pedersen and D. A. Mukoko, "Impact of insecticidetreated materials on filarial transmission by the various species of vector mosquito in Africa," Annals of Tropical Medicine and Parasitology, vol. 96, Supplement 2, pp. S91-S95, 2002.

[40] J. E. Mokry, "A method for estimating the age of field-collected female Simulium damnosum s.1. (Diptera: Simuliidae)," Tropenmedizin und Parasitologie, vol. 31, no. 1, pp. 121-124, 1980.

[41] N. Kolstrup, J. E. McMahon, and S. A. Magayuka, "Control measures against bancroftian filariasis in coastal villages in Tanzania," Annals of Tropical Medicine and Parasitology, vol. 75, no. 4, pp. 433-451, 1981. 
[42] J. C. Anosike and C. O. E. Onwuliri, "Experimental Wuchereria bancrofti infection of Culex quinquefasciatus and Aedes aegypti," Angewandte Parasitologie, vol. 33, no. 3, pp. 139-142, 1992.

[43] J. Brengues, La FiLariose de Bancroft en Afrique de L'Ouest, vol. 79, Orstom, 1975.

[44] G. S. Nelson, R. B. Heish, and M. Furlong, "Studies in filariasis in East Africa. II. Filarial infections in man and mosquitoes on the Kenya coast," Transactions of the Royal Society of Tropical Medicine and Hygiene, vol. 56, pp. 202-217, 1962.

[45] G. B. White, "Studies on transmission of bancroftian filariasis in North-eastern Tanzania," Transactions of the Royal Society of Tropical Medicine and Hygiene, vol. 65, no. 6, pp. 819-829, 1971.

[46] F. Kuhlow, "Observations and experiments on Culex antennatus (Becker) as a potential vector of Bancroftian filariasis in West Africa," Tropical Medicine and Parasitology, vol.38, pp. 349-350, 1987.

[47] P. J. Southgate, "Biology of bruchidae," Annual Review of Entomology, vol. 24, pp. 449-473, 1979.

[48] P. E. Simonsen, D. W. Meyrowitsch, W. H. Makunde, and P. Magnussen, "Bancroftian filariasis: the pattern of microfilaraemia and clinical manifestations in three endemic communities of Northeastern Tanzania," Acta Tropica, vol. 60, no. 3, pp. 179-187, 1995.

[49] H. J. Maasch, "Quantitative Untersunchungen zur Ubertragung von Wuchereria bancrofti in der Kustenregion Liberias," Zeitschrift für Tropenmedizin und Parasitologie, vol. 24, no. 4, pp. 419-434, 1973.

[50] R. Subra, "Urbanization et filariose de bancroft en Afrique et a Madagascar," Cahiers ORSTOM Série Entomologie Médicale et Parasitologie, vol. 13, no. 4, pp. 193-203, 1975. 

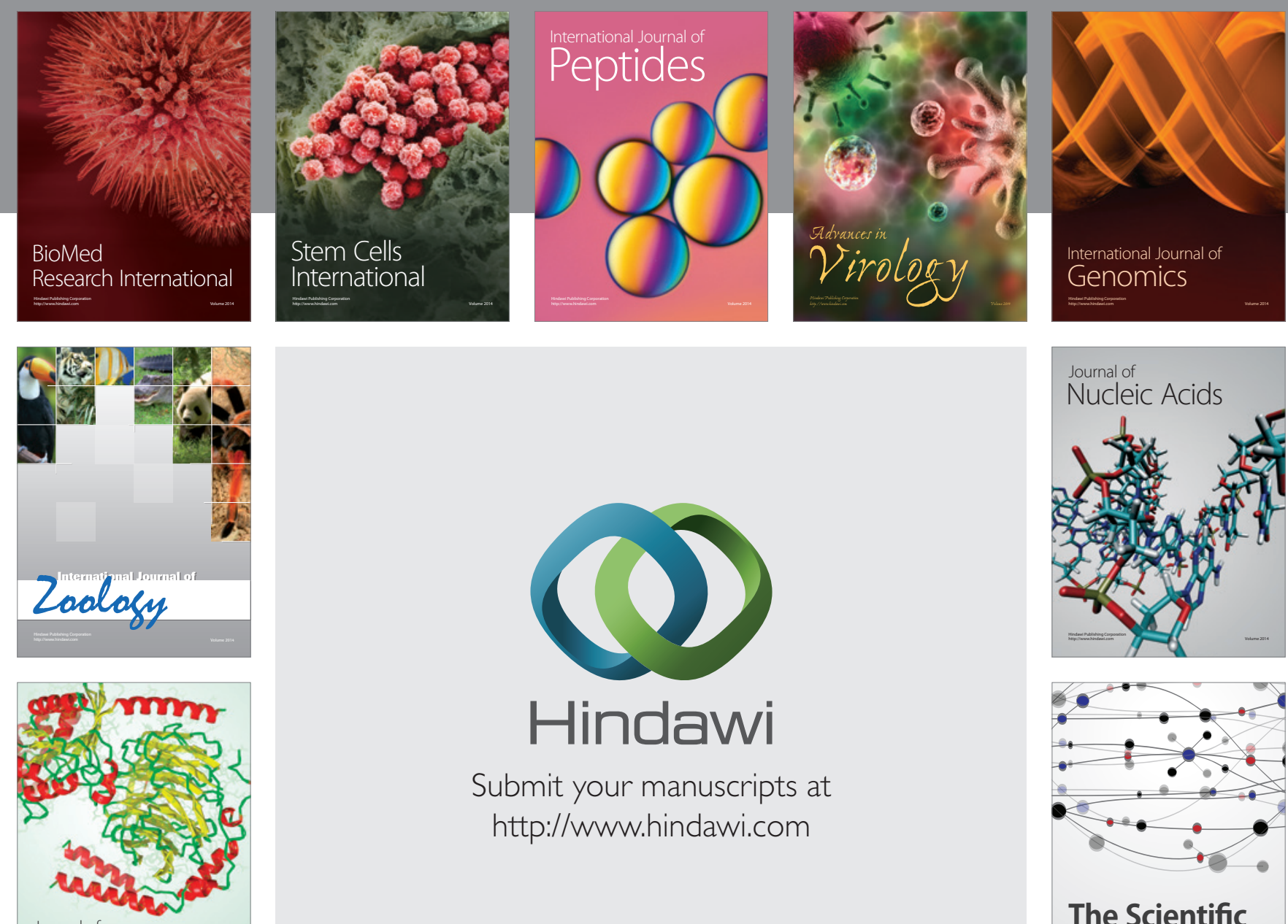

Submit your manuscripts at

http://www.hindawi.com

Journal of
Signal Transduction
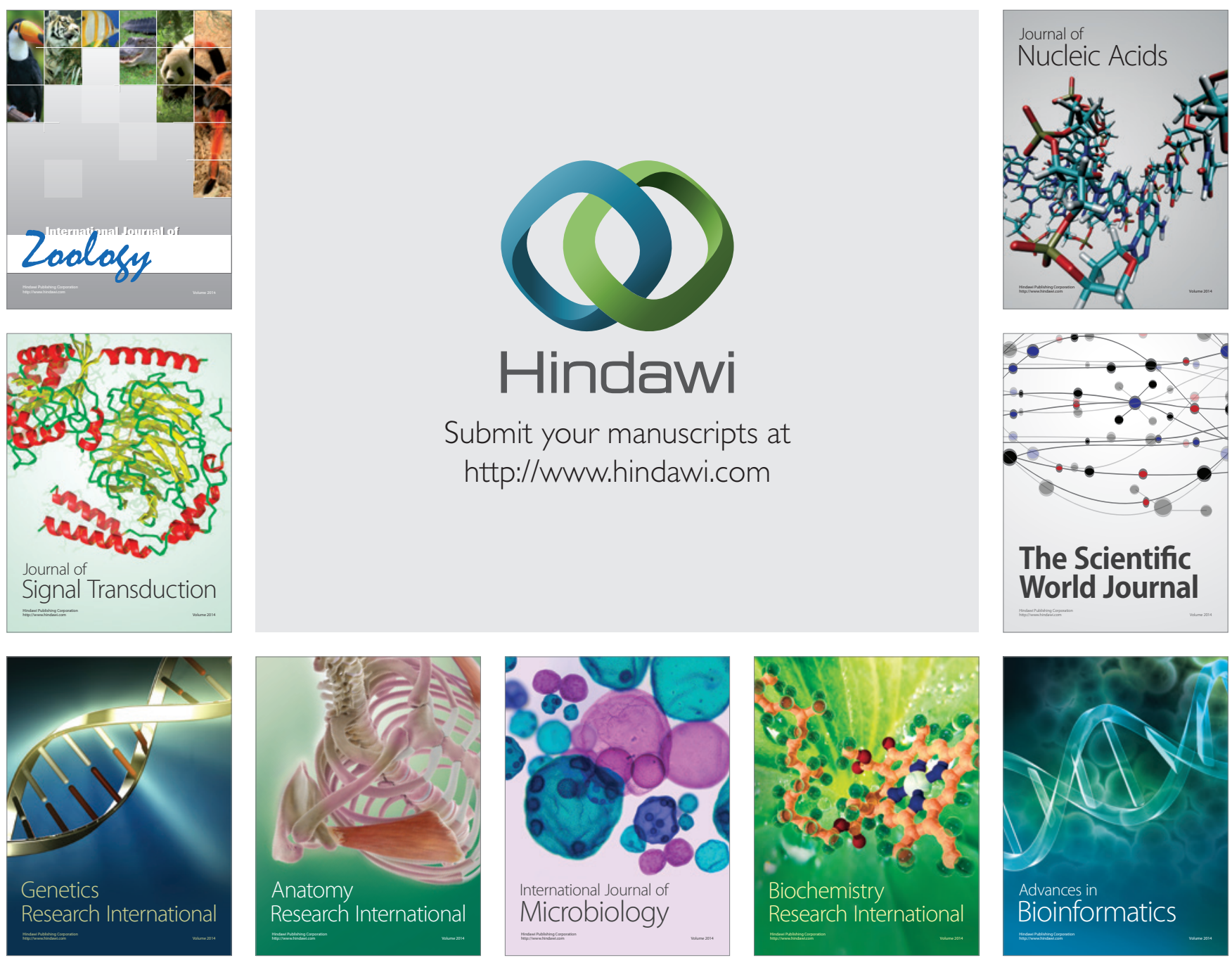

The Scientific World Journal
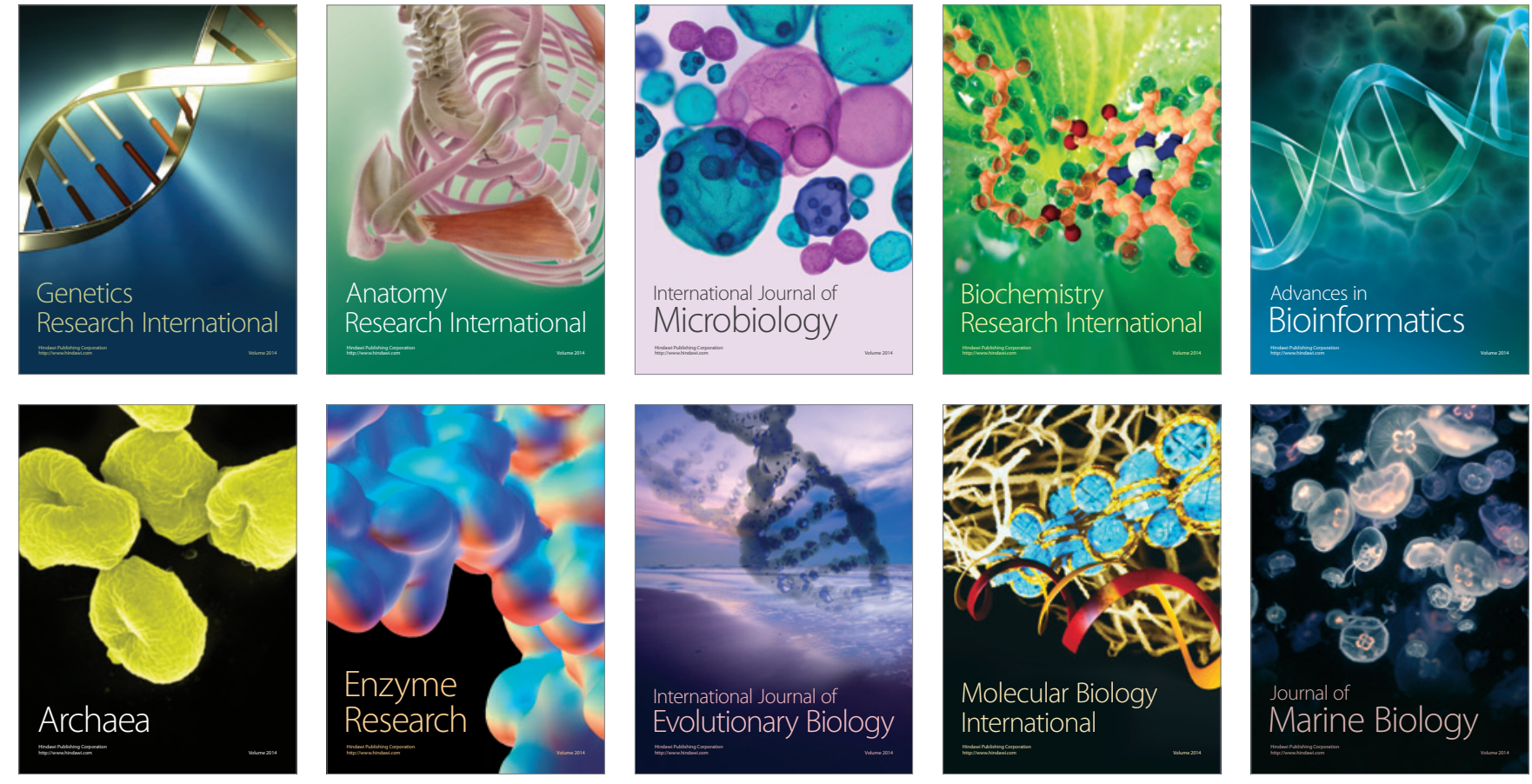